\title{
DEVELOPING EFL LEARNERS' ACHIEVEMENT COMMUNICATION STRATEGIES IN A SPEAKING CLASS
}

\author{
Syarifudin \\ English Education Department, Faculty of Educational Science and Teacher Training \\ State Institute for Islamic Studies (IAIN) of Mataram \\ Email: lafudin@gmail.com
}

\begin{abstract}
Abstrak
Strategi komunikasi perlu dimasukkan dalam perkuliahan speaking untuk memungkinkan mahasiswa memiliki strategi untuk mengatasi masalah atau kesulitan yang dihadapi dalam komunikasi lisan, baik sebagai pengirim pesan (speaker) maupun sebagai penerima pesan (listener) dalam berinteraksi lisan. Ketika pengirim dan penerima pesan menghadapi masalah dalam berkomunikasi secara lisan, mereka dapat menggunakan strategi komunikasi sebagai pengganti pesan verbal dan nonverbal yang sulit diungkapkan atau dimunculkan, sebagai upaya untuk mengatasi masalah dalam berkomunikasi secara langsung dengan menggunakan cara alternatif dalam rangka mendapatkan atau memunculkan pesan yang disampaikan atau yang diterima. Penggunaan strategi komunikasi semacam ini dianggap sebagai perilaku yang baik dalam berkomunikasi, karena pembicara dan lawan bicara mampu menjaga komunikasi agar tetap berjalan dengan baik. Pembicara sebagai pengirim pesan (speaker) dan penerima pesan (listener) dapat menggunakan strategi komunikasi verbal dan non-verbal untuk mengatasi masalah komunikasi, strategi komunikasi tersebut adalah menciptakan kata baru (word coinage), pengalihan bahasa (language switch), parafrase (paraphrase), penggambaran karakteristik kosa kata bahasa target (circumlocution), strategi kooperatif (cooperative strategies), terjemahan harfiah (literal translation), meminta bantuan (appeal for assistance), mengasingkan bahasa sumber (foreignizing) mengkoreksi bahasa sendiri (self-correction), meminta pengulangan (asking for repetition), meminta klarifikasi (asking for clarification), strategi non-linguistik (non-linguistic strategies), dan sebagainya. Sementara itu, strategi komunikasi nonverbal yang dapat digunakan oleh pengirim pesan (speaker) dan penerima pesan (listener) dapat berupa tersenyum, menganggukkan kepala, menggelengkan kepala , mengangkat tangan, menggerakan tangan, mengangkat jempol, menggambarkan/ menguraikan sesuatu, dan sebagainya.
\end{abstract}

Keywords: Strategi Komunikasi, Pembelajar EFL, Kelas Speaking.

\begin{abstract}
Communication strategies should be included in a speaking class in order to enable learners have strategies to cope with the communication problems both as message delivers (speakers) and as message receivers (listeners) in taking turns speaking. When the learners face problems in taking turns speaking, they may employ achievement/compensatory strategies as an attempt to deal with problems in communication directly by using alternative in order to get the message across. The use these strategies are regarded as good learners' behaviors because they are able to maintain communication, such as use of word coinage, language switch, paraphrase, circumlocution, cooperative strategies, non-linguistic strategies, and so forth. Otherwise, the learners may rely on the
\end{abstract}


avoidance/reduction strategies if they are not able to convey or understand the message to or from the interlocutors. These behaviors affect interaction negatively and are common among low proficiency learners. The avoidance message as such topic avoidance, message abandonment, replace the message, reduce the content of the intended message, and so forth. Learners as message delivers (speakers) and message receivers (listeners) may use verbal communication strategies to cope with communication problems, such as topic avoidance, message abandonment, approximation, word coinage, circumlocution, literal translation (interlingual transfer), language switch, appeal for assistance, foreignizing (interlingual transfer), paraphrase, self-correction, selfrepetition, asking for repetition, asking for clarification, and so forth. Meanwhile, nonverbal CSs which may be employed by learners as message senders (speakers) and message receivers (listeners) are smiling, head nodding, head shaking, hand raising, hand moving, thumb up, drawing something, and so forth.

Keywords: communication strategies (CSs), EFL Learners, speaking class.

\section{INTRODUCTION}

In the context of English as a Foreign Language (EFL), it has been widely claimed by most Indonesian learners across different levels of education that speaking is a difficult skill to learn. Shumin (2002:204) stated that "speaking a language is especially difficult for foreign language learners because effective oral communication requires the ability to use the language appropriately in social interactions". Shumin's statement may indicate that learners encounter problems in using the target language (TL) in oral communication if they do not have adequate communicative competence that underlies speaking proficiency.

Regarding the learners' problems in speaking English, there are some reasons why speaking is considered as a language skill which is difficult to be acquired by most of learners. One of the reasons is that speaking requires the ability to use the appropriate, acceptable and comprehensible spoken language through communication in many kinds of opportunities. Opportunities are available for the learners who want to communicate in English both inside and outside the classroom activities, but in fact, the learners are sometimes reluctant to participate in speaking activities. This coincides with Ur (1996:121) who stated that there are some problems with 
speaking activities in which learners are often inhibited about trying to say things in a foreign language in the classroom and afraid of making mistakes; they have no motive to express themselves beyond the guilty feeling that they should be speaking, and low or uneven participation. Supporting Ur, Padmadewi (1998) based on her investigation, asserted that learners attending a speaking class often felt anxious due to pressure from the speaking tasks that require them to present speaking tasks individually and spontaneously within limited time. In line with Padmadewi's (1998) argument, Tutyandari (2005) in her investigation commented that the learners keep silent because they lack of self-confidence, lack of prior knowledge about the topics, and poor of teacher-learner relationship. Besides those problems, it may be suspected that another learners' problem is related to their lack of grammatical competence which is the use of the linguistic system that includes increasing expertise in phonology, morphology, syntax, and lexical (vocabulary).

In a taking turns speaking, although the learners have many communication problems, they are encouraged to participate in speaking both monologue and dialogue speaking activities in order to habituate and familiarize them with communication in the target language (TL). A speaking class is one way of practicing and learning of speaking, but multitudes of opportunities for learning and practicing speaking or communication exist in context in which English needs to be used. In multitudes of opportunities someone can share to many others which engender speaking events in environment of natural setting.

Knowing the learners' problems and the empirical evidence in taking turns speaking is of utmost importance. It has inspired the writer to involve the communication strategies (CSs) in teaching speaking. Although the learners always practice to speaking and communicating in English in their speaking classes, they still face many problems in oral communication both in conveying and receiving messages to and from the interlocutors. Taking 
account of the problems in communication, it is necessary to form a variety of communication strategies (CSs) as the essential aspect needed to overcome communication problems in the TL situation. Since speaking strategies are in most cases discussed under the broader domain of communication strategies (CSs), it is better to have a look at those issues in order to have a clear understanding of communication strategies.

\section{DISCUSSION}

\section{Communication Strategies of different Perspective and Taxonomy}

Communication strategies have been an extremely important topic of discussion when it comes to second and foreign language learning, particularly in oral communication. The learners as speakers and as listeners may encounter various communication problems when they are limited competencies in the target language, and they may attempt to surmount the problems by employed some tricks or strategies to enhance the achievement of communication goals. In order to convey the messages and maintain them in a speaking activity until communication purposes are reached, the learners need to employ speaking strategies (SS) which are commonly referred to communication strategies (CSs).

Communication strategies are defined as "a mutual attempt of two interlocutors to agree on a meaning in situations where requisite meaning structures do not seem to be shared" (Tarone, 1983:65). Tarone's perspective of communication strategies may be seen as attempts to bridge the gap between the linguistic knowledge of the speaker and the listener to the target language in real communication situation. Achievement/compensatory strategies may be used to bridge this gap, while avoidance/reduction strategies may be used where the gap is perceived as unbridgeable. Similar to Tarone, Bialystok (1983:102) also defined communication strategies as "all attempts to 
manipulate a limited linguistic system in order to promote communication." Bialystok's perspective about communication strategies may be seen as demeanors for those cases in which communication is disrupted because of an inadequate linguistic knowledge and an impasse in the minds of what they are talking in the target language of both speakers and listeners.

In line with Tarone and Bialystok, Faerch and Kasper (1983:212) defined communication strategies as "the potentially conscious plans for solving what to an individual presents itself as a problem in reaching a particular communicative goal." According to them, when speakers cannot find a way to communicate without problems, they turn to strategies to deal with the problems they encounter while communicating. This coincides with Corder (1981:102) who defined communication strategies as "a systematic technique employed by a speaker to express his meaning when faced with some difficulty".

This means that the learners' communication strategies are seen as tools to improve the speaking ability. One of the main criteria in determining the quality of speaking ability is based on the use of an appropriate communication strategy "in a joint negotiation of meaning where both interlocutors are attempting to agree as to a communicative goal" (Tarone, 1980:420). That is why CSs are also considered as the pivotal strategies since they are as the ways to solve the problems of communication. In addition, the position of communication strategies is very important and they are an undeniable event of language use.

Tarone's (1983) research is in the form of analyzing transcripts of the learners' attempts to refer to a number of objects and events depicted. The learners' productions are interactional, which reflect learner's attempts to make themselves understood by their interlocutors. By focusing on interactions, Tarone regards communication strategies as any attempts at avoiding disruptions of communication. 
Tarone (1983:62-63) further categorized the existence of communication strategies that happen in learners' speaking or interaction which is commonly known as Torone's taxonomy of communication strategies. She depicted the taxonomy of communication strategies into five main categories as in Table 1.

Table 1.

Taxonomy of Communication Strategies (Tarone,1983:62-63)

\begin{tabular}{cccc}
\hline No & $\begin{array}{c}\text { Communication } \\
\text { Strategy }\end{array}$ & $\begin{array}{c}\text { Description of } \\
\text { Strategy }\end{array}$ & Examples \\
\hline 1 & Avoidance & &
\end{tabular}

1 Avoidance

a. Topic avoidance The learner simply tries The learner does not to talk about not respond to concepts for which the the topic or TL item or structure is keeps silent. not known.

b. Message abandonment

\section{Paraphrase}

a. Approximation

b. Word coinage

c. Circumlocution
The learner begins to talk about a concept but is unable to continue and stops in midutterance.

The learner uses of a single target language vocabulary item or structure, which the learner knows is not correct, but which shares enough semantic features in common with the desired item to satisfy the speaker.

The learner makes up a new word in order to communicate a desired concept.

The learner describes the characteristics or elements of the object or action instead of
Talk something then suddenly stops because it is too difficult.

'pipe' for 'waterpipe' 'airball' for 'balloon' 'a place for sleeping' for 'bed' 
3 Conscious Transfer

a. Literal translation

b. Language switch using the appropriate target language item or structure.

The learner translates word for word from the native language.

The learner uses the native language term without bothering to translate.

\section{Appeal for} assistance

5 Mime
The learner asks for the correct term or structure to any capable peers.

The learner uses nonverbal strategies in place of a lexical item or action.
'He invites him to drink, for 'they toast one another'

'balon' for 'ballon', 'tirtil' for 'caterpilar'I

'What is this? What called?'

'Clapping one's hand, shaking or nodding head, thumbs up, and thumbs down.

Faerch and Kasper (1983) adopted psycholinguistic approach in analysis communication strategies in which they locate communication strategies within a general model of speech production. The taxonomies of communication strategies to be included account for real phenomena, for which empirical evidence had been provided by various previous studies. Somewhat similar with Tarone's (1983) taxonomy, Faerch and Kasper (1983) developed taxonomy of communication strategies into four main categories. Those strategies can be seen in Table 2 . 
Table 2

Taxonomy of Communication Strategies (Faerch\& Kasper, 1983:38-52)

\begin{tabular}{|c|c|c|c|}
\hline No & $\begin{array}{c}\text { Communication } \\
\text { Strategy }\end{array}$ & Description of Strategy & Examples \\
\hline 1 & $\begin{array}{l}\text { Formal reduction } \\
\text { strategies } \\
\text { (reduction of the } \\
\text { linguistic system) } \\
\text { a. Phonological } \\
\text { b. Morphological } \\
\text { c. Syntactic } \\
\text { d. Lexical }\end{array}$ & $\begin{array}{l}\text { Learner attempts to do } \\
\text { away with a problem } \\
\text { and give up part of his } \\
\text { original } \\
\text { communicative goal. } \\
\text { Learner communicates } \\
\text { by means of a reduced } \\
\text { system, in order to } \\
\text { avoid producing non- } \\
\text { fluent or incorrect } \\
\text { utterances by using } \\
\text { insufficiently } \\
\text { automatized or } \\
\text { hypothetical } \\
\text { rules/items. }\end{array}$ & $\begin{array}{l}\text { a. Reducing } \\
\text { phoneme '/ðə/' } \\
\text { to 'loanwords'. } \\
\text { b. Reducing } \\
\text { morpheme 'es' to } \\
\text { 'she watch TV' } \\
\text { c. Reducing 'be' to } \\
\text { 'Don't afraid of } \\
\text { making mistakes. } \\
\text { d. Reducing lexeme } \\
\text { 'comb' to 'you tidy } \\
\text { your hair with..' }\end{array}$ \\
\hline 2 & $\begin{array}{l}\text { Functional } \\
\text { reduction } \\
\text { strategies } \\
\text { (reduction of } \\
\text { communicative } \\
\text { goal) } \\
\text { a. Actional } \\
\text { reduction } \\
\text { b. Modal reduction } \\
\text { c. Reduction of the } \\
\text { propositional } \\
\text { content. } \\
\text { - Topic } \\
\quad \text { avoidance } \\
\text { - Message } \\
\text { abandonment, } \\
\text { - Meaning } \\
\text { replacement }\end{array}$ & $\begin{array}{l}\text { Learner reduces his } \\
\text { communicative goal in } \\
\text { order to avoid a } \\
\text { problem. } \\
\text { These involve the } \\
\text { learner avoiding } \\
\text { certain speech acts or } \\
\text { discourse functions, } \\
\text { avoiding or } \\
\text { abandoning or } \\
\text { replacing certain } \\
\text { topics, and avoiding } \\
\text { modality markets. }\end{array}$ & \\
\hline
\end{tabular}




\section{Achievement strategies (compensatory strategies)}

a. Code switching b. Interlingual
transfer
c. Inter- /intralingual transfer
d. IL based strategies
Learner attempts
to solve
communicative problem by expanding
his communicative resources.

The learner uses a form in the non L2 language.

The learner makes use of other than the L2.
Do you want to have some ah-Zinsen or do you want to have some more...

NS: How do you go to school [...]

L: [...] sometimes I take my er

The learner makes use Swim -swimmed of alternative L2 forms.

The learner has various possibilities for coping with communicative problems by using his IL system.

\section{- Generalization The learner replaces} one L2 form with another.

- Paraphrase

The learner replaces an L2 item by describing or exemplifying it.

- Word coinage

- Restructuring

e. Cooperative strategies
The learner replaces an L2 item with an item made up from L2 forms.

The learner develops an alternative constituent plan.

These involve a joint problem solving effort
Do you have 'animals?' for 'rabbits'.

I have a car-I have bicycle-and have a motor.

We were sitting in the - rounding of the stadion.

My tummy-my tummy is- I have (inaudible) I must eat something. NS: what ercolour is it- 


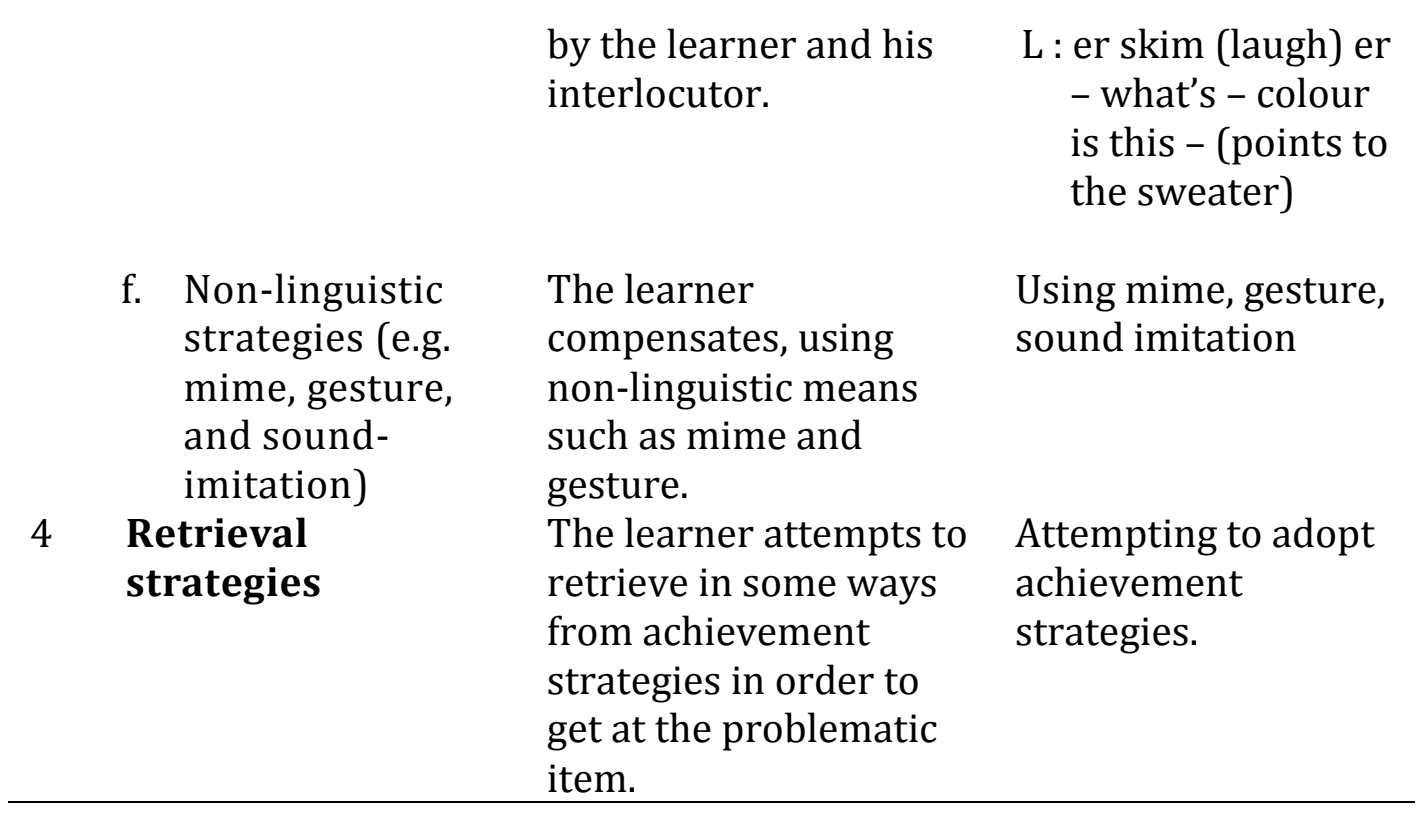

Furthermore, Faerch and Kasper illustrated a first broad categorization of communication strategies on the basis of two fundamentally different ways in which learners might behave when faced with problems in communication. Learners can either solve such problems by adopting 'avoidance behavior', trying to do away with the problem, normally by changing the communication goal, or by relying on 'achievement behavior', and attempting to tackle the problem directly by developing an alternative plan. On the basis of these two different approaches to problem solving, two major types of strategies namely reduction strategies and achievement strategies can be depicted. The former is governed by avoidance behavior, and the latter is governed by achievement behavior. The relationship between problem, type of behavior and type of strategy is presented in Figure 1. 


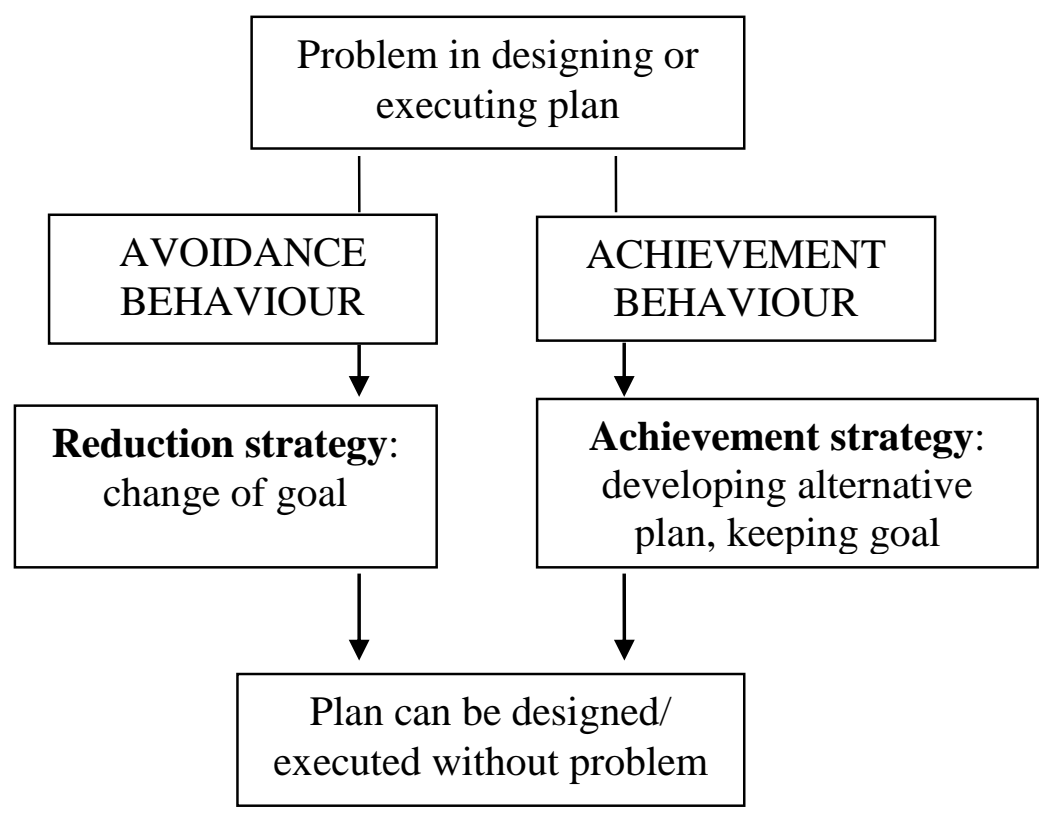

Figure 1

Types of Behavior and Types of Strategies (Faerch \& Kasper, 1983:37)

Knowing that both communication strategies taxonomies proposed by Tarone (1983), and Faerch and Kasper (1983) have similarity and dissimilarity. The similarity is in which some of those strategies seem not only to exist explicitly in each of taxonomy, but also to exist into each other, such as topic avoidance, message abandonment, paraphrase, word coinage, code switching, and non-linguistic strategies. Furthermore, classifying the differences of both two taxonomies are focused on the strategies perspectives and the types of strategies.

The differences come from, firstly the fact that Tarone (1983) views communication strategies from a discourse analytical perspective through interactional approach, which is believed that learners' speaking in interaction of real communication context is the one way to know the interaction process between speakers and their interlocutors, what strategies which are learners employed to cope with the problems in communication. Faerch and Kasper (1983) esteemed communication strategies verbal plan within a speech production through psycholinguistic approach, which is considered that mental processes of 
learners underlying their language behavior when dealing with problems of communication (grammatical, lexical and discourse) in speaking acts. Secondly, it seems that Tarone's (1983) taxonomy, not to differentiate the position of achievement/compensatory and avoidance/reduction strategies as the main categories, he explicitly stated such as avoidance, paraphrase, conscious transfer, appeal for assistance, and mime as the main categories. Meanwhile, Faerch and Kasper (1983) more clearly in categorizing the position of each communication strategies in which they explicitly stated achievement/ compensatory and avoidance/reduction strategies as the main categories, then following by sub-categories. In addition, they included the linguistic system and functional aspect in the taxonomy, so it seems to be more complex than what Tarone's (1983) work.

Concerning those various kinds of communication strategies proposed by Tarone (1983) and (Faerch and Kasper, 1983), they were able to be categorized into two types of strategies, namely achievement/compensatory strategies and avoidance/reduction strategies. Learners may employ achievement/compensatory strategies in an attempt to deal with problems in communication directly by using alternative in order to get the message across. They enable the learners "work on an alternative plan for reaching their original goal by means of whatever resources are available. These strategies are regarded as good learners' behaviors" (Nakatani, 2006:151). Through achievement/compensatory strategies there are some strategies in which the learners may employ in such as word coinage, language switch, paraphrase, circumlocution, interlingual transfer, intralingual transfer, cooperative strategies, non-linguistic strategies, and retrieval strategies. Otherwise, the learners may rely on the avoidance/reduction strategies if they are not able to convey or understand the message to or from the interlocutors. These strategies 
enable learners to avoid or reduce the message which they are not able to convey and understand. This coincides with Nakatani's (2006:151) argument that the "learners avoid solving communication problems and give up on conveying their message. These behaviors affect interaction negatively and are common among low proficiency learners". By means of avoidance/reduction strategies, the learners may avoid topic of message, message abandonment, replace the message, reduce the content of the intended message, formal reduction (using reduced system to avoid producing non-fluent or incorrect utterances) and function reduction strategies (avoiding a specific topic or giving up sending a message) so that they keep the message within their communication resources. Thus, those taxonomies here are not meant to be the final categorization of communication strategies, but they are used here as the needs of the starting point for using in a speaking class.

\section{Verbal and Nonverbal Communication Strategies}

Providing effective guidance in developing theories of verbal and nonverbal communication strategies, it is necessary to discern the difference between theories of verbal and nonverbal communication. The components of these theories are underpinning the theories of verbal and nonverbal communication strategies. Bialystok (1990:116) stated that communication strategies as part of general theory of communication which includes verbal and nonverbal communication. Strazny (2005:220) argued that so far we have concentrated on the two forms of verbal communication: written and oral communication, but human communication may also be nonverbal. This coincides with Hurt (2012:1) who argued that verbal and nonverbal communication are part of the backbone of people. They are necessary to people getting along with each other and building the cultures they call their own. Studying communication means understanding the basic of what make verbal and 
nonverbal communication both different and similar. It is possible to separate these two types of communication, but more often they occur together, especially in the face-to-face communications we engage in every day.

a. Verbal communication Strategies

In terms of verbal communication strategies, it necessitates to relate to verbal communication theories that underlie the theories of verbal communication strategies. Verbal communication often refers to the use of words or verbal languages in communication (Knapp and Hall, 2002:1). Verbal communication encompasses more than just spoken language, however, in this study is going to look closely to oral (spoken) communication. Lam ( 2006:142) stated that "strategies for second language (L2) oral communication are commonly known as communication strategies". In relation to the verbal communication, so verbal communication strategies are used to convey and receive or exchange of messages using orally spoken words or languages to overcome the problems which disrupt communication. Tarone (1983:62-63) and Faerch and Kasper (1983:38-52) depicted that verbal communication strategies such as approximation, word coinage, circumlocution, literal translation, language switch, paraphrase, restructuring, and using all strategies through words or spoken languages .Using these strategies can help improvement of learners' verbal communication skills.

Verbal communication, however, can also be used together with nonverbal communication concurrently. For instance, the relational perspective suggests that meaning construction between a speaker and hearer provides the context for interpersonal communication. In other words, when people meet others interpersonally, their primary task is to communicate who they are, particularly their attitudes toward relevant objects in the environment. The speaker infers 
similarity to his partner either from verbal or nonverbal cues. If similarity is detected, it is experienced as support to their attitudes and often results in increased interpersonal attraction (i.e. making friends, gaining acceptance) that can be done either through words or body language and gestures (Keegan, 2004).

b. Nonverbal Communication Strategies

With regard to nonverbal communication strategies, it is imperative to connect to nonverbal communication theories underlying the theories of nonverbal communication strategies. Nonverbal communication refers to communication that is produced by some means other than words such as eye contact, body language, or vocal cues (Knapp and Hall, 2002:1). Bonvillain (2005:35) explained that nonverbal communication makes use of both kinesics and proxemic acts. The term kinesics refers to gesture, facial expression, eye contact, and body postures, while proxemics includes uses of touch and definitions of personal space. In line with Bonvillain (2005), Panagiotis (2012) stated that nonverbal communication or body language strategies include facial expressions, gestures, eye contact, posture, and even the tone of our voice. In connection with nonverbal communication, then nonverbal communication strategies are the ways to convey the meaning through using body languages or all behaviors that are not words or nonverbal language.

Moreover, Thompson (2003:98) illustrated that the term nonverbal communication, or body language as it is also commonly known, refers to the bodily movements which accompany speech and which add meaning to the interaction. The term kinesics is used to refer to a study of movements in general, and so the study of nonverbal communication can be seen as a subdivision of kinesics. 
Nonverbal communication can be subdivided into a number of main components as follows.

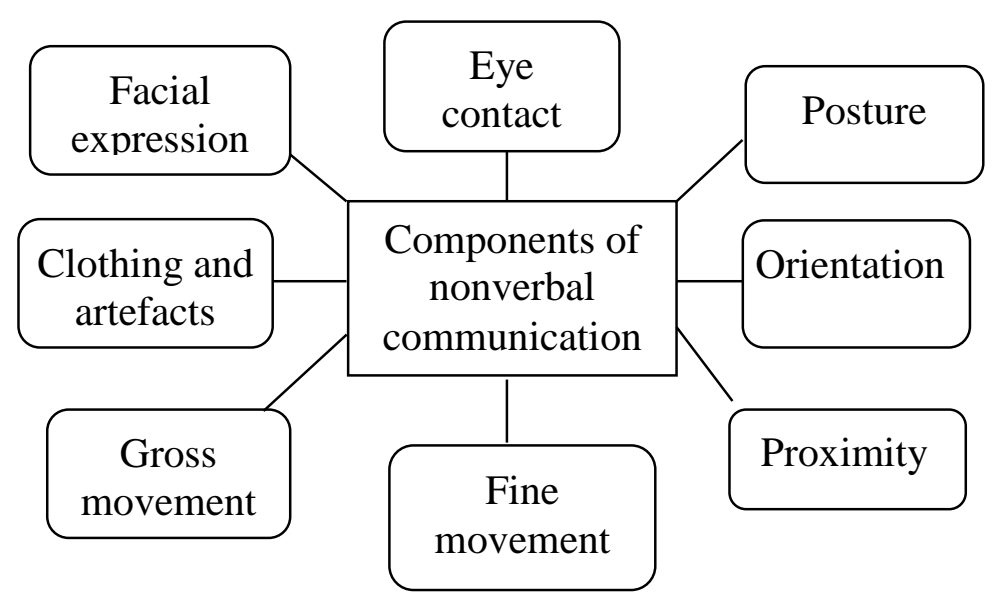

Figure 2

Components of Nonverbal Communication (Thompson, 2003: 98)

Facial expression. The people face is extremely expressive, able to express countless emotions without saying a word. Unlike some forms of nonverbal communication, facial expressions are universal. The facial expressions for happiness, sadness, anger, surprise, fear, and disgust are the same across cultures (Panagiotis, 2012). Facial expression is an important nonverbal strategy. It is "a powerful convey of meaning" (Harmer, 2007:44). Harmer further argued that smiling is an almost universal signal of pleasure or welcome. Other facial actions, such as biting lip (indicating thought or uncertainly), compressing the lips (to show decision or obstinacy), and visible clenching of the teeth to show anger are all powerful conveyors of meaning too. This is in line with (Thompson, 2003:97) who commented that facial expression can appear in a number of ways, but the most obvious use is smiling. However, this strategy also refers to other significant gestures such as raising an eyebrow. This is often one of the most noticeable aspects of nonverbal communication strategies, as it is very common practice for learners to look at each other's faces when communicating. 
Eye contact. Since the visual sense is dominant for most people, eye contact is an especially important type of nonverbal communication. The way people look at someone can communicate many things, including interest, affection, hostility, or attraction. Eye contact is also important in maintaining the flow of conversation and for gauging the other person's response (Panagiotis, 2012). This coincides with Thompson (2003:97) who argued that eye contact is very important and a very powerful means of communication. It can be used for a wide variety of purposes ranging from establishing solidarity and concern through to being threatening and intimidating. Eye contact conveys a lot about how people feel about themselves and the people they are communicating with.

Luft (2012) stated that eye contact have different meanings for different people. It is sometimes used to signify the gravity of a verbal statement. It can sometimes imply that more has been meant, or understood, than can easily be expressed verbally. It can provide a sense of emotional connection, with a variable degree of intimacy. It can also carry the suggestion (not necessarily correct) that no part of the truth is being with held from the receiver.

Posture. The posture we adopt in sitting or standing can say a lot about our frame of mind or our emotional state (Thompson, 2003:98). Harmer (2007:44) stated that posture can covey meaning, for example hunched shoulders and a hanging head give a powerful indication of mood. Furthermore, Panagiotis (2012) argued that consider how your perceptions of people are affected by the way they sit, walk, stand up, or hold their head. The way you move and carry yourself communicates a wealth of information to the world. This type of nonverbal communication includes your posture, bearing, stance, and subtle movements. 
Orientation. Whether we face towards someone or away from them can speak volumes about our attitude toward them, how we value them (or not) and perhaps even our intentions towards them. For example, turning away from someone can be very powerful gesture indeed (Thompson, 2003:98).

Proximity. How closely or otherwise we sit or stand in relation to someone can be very meaningful indeed. For example, many hospitable and friendly teachers have been taught out by fact that their proximity indicated to students a greater degree of intimacy (Thompson, 2003:98). Proximity is also both a matter of personal style and of culture: what may seem normal to a speaker from one culture may appear unnecessarily close or distant to a speaker from another. And standing close to someone may be quite appropriate in some situations such as an informal party, but completely out of place in others, such as a meeting with a supervisor (Harmer, 2007:44).

Fine movement. This refers to small movements of parts of the body which can be very significant, for example, a nod of the head, a wave of the hand or a furrowing of the brow. These can often be very subtle, but none the less very significant in the message they convey and the impression they create (Thompson, 2003:98).

Cross movement. This refers to more large-scale movement of the body of parts of the body. Walking or running away from someone would like the clear examples of this. These are often associated with more extreme situations, but do none the less occur quite frequently. For example, at a social gathering, someone may talk the long way round to where they want to go in order to avoid a particular individual that they do not wish to interact with (Thompson, 2003:98). 
Clothing and artefacts. In the majority of situations, the clothing we wear will say something about how we perceive that situation. For example, wearing formal clothing at a court appearance or job interview indicates respect and that we are taking the proceedings seriously (Thompson, 2003:98).

Gestures. Gestures are woven into the fabric of people daily lives. People wave, point, beckon, and use their hands when they are arguing or speaking animatedly, expressing themselves with gestures often without thinking. However, the meaning of gestures can be very different across cultures and regions, so it is important to be careful to avoid misinterpretation (Panagiotis, 2012). In terms of gesture strategy, it includes purposeful of head, shoulders, arms, hand, or some other part of the body to deliver or receive messages in communication. The learners often use gestures strategies in speaking, even though they may not be aware of them. Harmer (2007:44) explained that using gestures strategies to indicate wide range of meanings, although the actual gestures the learners use may be specific to the particular cultures.

However, using of nonverbal with verbal CSs helps to deliver the messages more effectively. Thompson (2003:82) argued that nonverbal strategy is not only an important part of assertiveness, but also as a significant part of successful interpersonal encounters in general. It also refers to the bodily movements which accompany speech and which add meaning to the communication. This coincides with Faerch and Kasper (1983:52) who argued that although nonverbal strategies are sometimes used as the learners' one and only attempt at solving a communication problem; they are often used to support other verbal strategies. Learners convey the meaning not only through verbal strategies but also through nonverbal strategies. 


\section{CONCLUSION}

Communication strategy (CS) can benefit the learners in improving their English speaking skill and also is considered as the matter that facilitate the learners when linguistic and sociolinguistic knowledge is limited in conveying and understanding the message with interlocutors in taking turns speaking. Other benefits of communication strategies, such as the learners' speaking proficiency development is influenced by their ability to use communication strategies; and they lead the EFL learners to learn by eliciting unknown TL words from the interlocutors. The use of a communication strategy in oral communication is not an indication of communication failure, but it is a part of language use which can be very successful for the learners to surmount their communication problems to reach communication goals.

Achievement/compensatory strategy is an attempt to deal with problems in communication directly by using alternative in order to get the message across. It enables the learners "work on an alternative plan for reaching their original goal by means of whatever resources are available. Through achievement/compensatory there are some strategies in which the learners may employ in such as word coinage, language switch, paraphrase, circumlocution, interlingual transfer, intralingual transfer, cooperative strategies, non-linguistic strategies, and and so forth. Otherwise, the learners may rely on the avoidance/reduction strategies if they are not able to convey or understand the message to or from the interlocutors. These strategies enable learners to avoid or reduce the message which they are not able to convey and understand. By means of avoidance/reduction strategies, the learners may avoid topic of message, message abandonment, and so forth.

Verbal communication strategies such as topic avoidance, message abandonment, approximation, word coinage, circumlocution, literal translation, language switch, appeal for assistance, foreignizing, paraphrase, 
self correction, comprehension check, self-repetition, restructuring, and using all strategies through words or spoken languages. Meanwhile, nonverbal communication makes use of facial expression (as such smilling and laughing), eyes contact, and gestures( as such head nodding, head shaking, hand raising, hand moving, thumb up, drawing something, and so forth).

\section{REFERENCES}

Andersen, Peter A. 1999. Nonverbal Communication: Forms and Functions (Mountain View, CA: Mayfield, (Online), 1:1-47, (http://www.docjax.com), retrieved March 20, 2014.

Bialystok, Ellen. 1983. Some factors in the selection and implementation of communication strategies. In Claus Faerch \& Gabriele Kasper (Eds.), Strategies in Interlanguage Communication (p. 100-118). New York: Longman Inc.

Bialystok, Ellen. 1990. Communication strategies: A Psychological Analysis of Second Language Use. Cambridge: Basil Blackwell.

Bonvillain, Nancy. 2005. Language, Culture, and Communication: The Meaning of Messages (Fourt Edition). New Jersey: Prentice Hall.

Brown, H. Douglas. 2000. Principles of Language Learning and Teaching. San Fransisco: Longman.

Brown, H. Douglas. 2007. Teaching by Principle: An Interactive Approach to Language Pedagogy. San Fransisco: Longman.

Dornyei, Zoltan. 1995. On the teachability of communication strategies. TESOL Quarterly, (Online), 29: 55-85, (http://www.docjax.com), retrieved March 14, 2011

Dornyei, Zoltan. 2002. Motivational Strategies in the Language Classroom. Cambridge: Cambridge University Press. 
Dornyei, Zoltan \& Scott, Mary Lee. 1997. Review Article Communication strategies in Second Language: Definitions and Taxonomies. Language Learning, (Online), 47 (1): 173-202, (http://www.docjax.com), retrieved March 14, 2011.

Faerch, Clause \& Kasper, Gabriele. 1983. On identifying communication strategies in interlanguage production. In Claus Faerch \& Gabriele Kasper (Eds.), Strategies in Interlanguage Communication (p. 210238). New York: Longman Inc.

Faucette, Priscilla. 2001. A Pedagogical perspective on communication strategies: Benefits of training and analysis of English language teaching materials. Second Language Studies, (Online), 19 (2): 1-40, http://www.docjax.com), retrieved May 17, 2011.

Fussell, S. R. 2001. The Verbal Communication of Emotion: Introduction and Overview. New York: Carnegie Mellon University.

Guerrero, Laura K. \& Floyd, Kory. 2006. Nonverbal Communication in Close Relationships: LEA'S Series on Personal Relationship. New Jersey: Laurence Erlbaum Associates.

Harmer, Jeremy. 2007. The Practice of English Language Teaching (Fourth Edition). England: Pearson Longman.

Huang, Chiung-Ping. 2010. Exploring Factors Affecting the Use of Oral Communication Strategies, (Online), ((http://www.docjax.com), retrieved December 10, 2011.

Hurt. A. E. 2012. Six Concepts of Verbal and Nonverbal Communication. (Online), (http://www.docjax.com), retrieved December 14, 2012.

Juan, Esther Uso \& Flor, Alicia Martinez. 2008. Teaching Intercultural Communicative Competence through the Four Skills. Revista Alicantina de Estudios Ingleses, (Online), 21: 157-170, (http://www.docjax.com), retrieved March 14, 2011.

Karimnia, Amin \& Zade, Shahram Salehi. 2007. Communication Strategies: English Language Department in Irak. Iranian Journal of Language 
Studies, (Online), 1 (4): 287-298, (http://www.docjax.com), retrieved February 17, 2012.

Keegan. 2004. Nonverbal Communication. Chapman University. http://en.wikipedia.org/wiki/body Language. Retrieval in December, 2012.

Knapp, M. L., \& Hall, J. A. 2002. Nonverbal Communication in Human Interaction. Crawfordsville: Thomson Learning.

Luft, J, Ingham, H. 2012. Non-verbal Communication. "The Johari window, a graphic model of interpersonal awareness", Proceedings of the western training laboratory in group development. Los Angeles: UCLA. (Online), (http://www.wanterfall. com), retrieved December 14, 2012

Maleki, Ataollah. 2010. Techniques to Teach Communication Strategies. Journal of Language Teaching and Research, (Online), 1 (5):640-646, (http://www.docjax.com), retrieved February 17, 2012.

Mei, An \& Nathalang, Sanooch. 2010. Use of Communication Strategies by Chinese EFL Learners. Chinese Journal of Applied Linguistics (Biomontly), (Online), 33 (3): 110-125, (http://www.docjax.com), retrieved February 17, 2012.

Nakatani, Yasuo. 2006. Developing an Oral Communication Strategy Inventory. The Modern Language Journal, (Online), 90 (ii): 151-168, (http://www.docjax.com), retrieved December 14, 2011.

Nakatani, Yasuo \& Goh, Christine. 2007. A review of oral communication strategies: focus on interactionist and psycholinguistic perspectives. In Andrew D. Cohen \& Ernesto Macaro (Eds.), Language Learner Strategies: Thirty Years of Research and Practice (p. 207-227). New York: Oxford University Press.

Padmadewi, N. N. 1998. Students' anxiety in speaking class and ways of minimizing it. Jurnal Ilmu Pendidikan, 5 (Supplementary Edition, 60-67). 
Panagiotis, Stamatis. 2012. Nonverbal Communication Skills. Online Course Materials, (Online), (http://www.docjax.com), retrieved December $10,2012$.

Shumin, Kang. 2002. Factors to Consider: Developing Adult EFL Students' Speaking Abilities. In Jack C. Richards and Willy A. Renandya (Eds.), Methodology in Language Teaching: An Anthology of Current Practice (204-211). Cambridge, Cambridge University Press.

Somsai, Surapa \& Intaraprasert, Channarong. 2011. Strategies for coping with face-toface oral communication problem employed by Thai university students majoring in English. GEMA Online Journal of Language Studies, (Online), 11 (3), (http://www.docjax.com), retrieved December 14, 2011.

Tarone, Elaine.1980. Communication strategies, foreigner talk and repair in interlanguage. Language Learning, (Online), 30:417-431, (http://www.docjax.com), retrieved December 14, 2011.

Tarone, Elaine.1983. Some thoughts on the notion of communication strategy. In Claus Faerch \& Gabriele Kasper (Eds.), Strategies in Interlanguage Communication (p. 61-74). New York: Longman Inc.

Thompson, Neil. 2003. Communication and Language: A handbook of theory and practice. New York: Palgrave Macmillan.

Tutyandari, C. 2005. Breaking the silence of the students in an English language class. Paper presented at the 53 rd TEFLIN International conference, Yogyakarta, Indonesia.

Ur, Penny. 1996. A Course in Language Teaching: Practical and Theory. Cambridge: Cambridge University Press.

Ya-ni, Zhang. 2007. Communication Strageties and Foreign Language Learning. US-China Foreign Language, (Online), 5 No.4 (Serial No.43): 43-48, (http://www.pdf.finder.com), retrieved December 10, 2011. 